Чиликина Ксения Васильевна

студентка

Халиуллина Лилия Фаритовна

студентка

Институт гидротехнического и энергетического строительства

ФГБОУ ВО «Национальный исследовательский

Московский государственный строительный университет»

г. Москва

\title{
ЭКОЛОГИЯ БЕТОНА
}

Аннотация: данная статья рассматривает экологичность бетонов за весь жсизненный ичкл данного материала, его преимущества и недостатки с точки зрения экологии, возможности снижения экологического ущеерба.

Ключевые слова: бетон, портландичемент, экология, цуемент, строительство, иммобилизатор, стабилизатор.

Abstract: this article examines the ecological compatibility of concrete throughout the life cycle of this material, its advantages and disadvantages in terms of ecology, the possibility of reducing environmental damage.

Keywords: concrete, portlandcement, ecology, cement, construction, immobilizer, stabilizer.

Традиционно бетон считается одним из самых экологичных видов строительных материалов. Именно с применением бетонных смесей возводится большинство зданий и сооружений.

Представим традиционный вариант бетона. Это цемент, смешанный с крупным (гравий, известняк или гранит) и мелким (в большинстве случаев песок) заполнителями, который разводят водой до полного и равномерного распределения вяжущего вещества. Далее образовавшуюся смесь формуют в необходимые 
для строительства изделия, после чего бетон твердеет и превращается в достаточно прочный камнеподобный материал.

Однако, стоит учитывать экологичность не только самого материала, но и экологию изготовления. При изготовлении портландцемента, связующего вещества в бетоне, выделяется колоссальное количество углерода в атмосферу, до 5\% общемирового выброса. В результате образуются парниковые газа. Кроме того стоит учитывать, что для создания цемента требуется большое количество воды и тепловой энергии (для создания высокой температуры). Для добычи песка разрабатываются карьеры, что тоже влияет на разрушение и загрязнение окружающей среды.

Далее рассмотрим «жизнь» бетонного изделия, когда его срок эксплуатации подошел к концу. С этим связан также ряд проблем. В одной только России ежегодно образуется около 6 миллионов тон строительных отходов, к которым относятся различные каменные материалы, бетон и железобетон и др. Кроме того, в результате новой реформы ЖКХ ожидается прирост бетонного лома до 15-17 миллионов тонн в год.

Рассматривая влияние железобетонных зданий на человека, связанное с тем, что бетон в некоторых случаях может быть источникам загрязнения среды при выделении некоторых неорганических элементов, в том числе и солей тяжелых металлов, летучих выделений то если негативное влияние и есть, то оно ничтожно мало по сравнению с различными другими вредными факторами.

Что же можно сделать, как еще больше сократить экологический ущерб от применения столь полюбившегося материала? Во-первых, можно использовать строительные отходы в производстве (в качестве крупного заполнителя в последующем приготовлении бетонных смесей и т. п.), тем самым сократив использование природных ресурсов, удешевив производство и освобождая земельные площади (свалки становятся меньше, и, как следствие - экологическая ситуация улучшается). В нашей стране переработкой строительных отходов занимаются уже более 60 лет. 
Чтобы снизить выброс большого количество углекислого газа, британская компания Novacem разработали бетон, который при затвердевании, впитывает в себя большое количество углекислого газа. Новая версия материала включает в себя сульфат магния, которая позволяет экономить тепловую энергию. Разработчики компании Novacem, утверждают: что каждая тонна цемента новой версии поглощает до 0,6 т. СО2, а по старой, наоборот, выделяет около 0,4 т. СО2. Однако, данная технология еще изучается, и не используется в массовом производстве.

В целом бетон можно считать экологичным материалом, не представляющим практически никакого вреда для окружающей среды, в том числе и для питьевой воды. Более того, может служить защитой от радиационного и химического воздействия, выполняя роль так называемого иммобилизатора и стабилизатора.

\section{Список литературы}

1. Новые технологии: экологически чистый бетон [Электронный ресурс]. Режим доступа: http://nerudr.ru/staty/novye_razrabotki_ekologicheski_chistyy_be ton.php

2. EcoPortal: вся экология [Электронный ресурс]. - Режим доступа: https://eco portal.su/news.php?id=94802

3. Строительство и недвижимость [Электронный ресурс]. - Режим доступа: http://www.nestor.minsk.by/sn/2004/24/sn42415.html

4. Nature time: сайт экологической грамотности [Электронный ресурс]. - Peжим доступа: https://nature-time.ru/2013/12/ekologichnyie-materialyi-v-stroitelstve/ \#i-4 